\title{
Quantity Exactness
}

National Cancer Institute

\section{Source}

National Cancer Institute. Quantity Exactness. NCI Thesaurus. Code C94848.

A description of how a particular amount was assessed. 